\title{
Viewing and Acting (and points in between): \\ the trouble with spectating after Rancière
}

Andy Lavender

Many recent events and performance pieces have challenged the distinction between viewing and acting, from the promenade performance experiences organised by Punchdrunk, to the games-based events of Blast Theory, to immersive installations by, for instance, Anthony Gormley and Olafur Eliasson, to the incorporation of 'experts' of the everyday in the work of Rimini Protokoll. If such work were in search of a manifesto, it might find it in Jacques Rancière's The Emancipated Spectator. ${ }^{1}$ Rancière's account - that of a provocateur - explores a philosophical and political framework for spectatorship that bears directly on this gathering artistic trend.

One of the delights of The Emancipated Spectator has been the prospect of taking at least parts of it literally. It sometimes appears to exhort us to participate rather than spectate, act rather than watch - we hear a call to the barricades. Its saliency resides in its application to a wider array of spectator transactions, including those where you don't necessarily have to leave your seat in order to enter the playing arena, nor stop watching in order to be in action. Rancière is concerned with the political aspect of spectating by way of spectators having a place, and knowing what that place can be and

\footnotetext{
1 Jacques Rancière, The Emancipated Spectator, trans. by Gregory Elliott (London and New York: Verso, 2009). First published in French as Le spectateur émancipé (Editions La Fabrique, 2008).
} 
mean. People can remain spectators in the midst of various degrees of emancipation. The Emancipated Spectator also lends itself to forms of heightened viewing, whereby spectators at (for example) multimedia installations, promenade performances and sports matches can experience themselves in the act of watching. Rancière doesn't directly focus on the nature of such experience. I shall suggest below that his analysis can be turned towards this double-edged development in cultural consumption.

To be precise, The Emancipated Spectator is the title of both a short essay and a collection of writings that derive from a series of talks and articles presented between 2004-2008. This seems worth mentioning, because it indicates the iterative and accumulative nature of Rancière's intellectual production, and the historical contiguity of these particular pieces with the artistic outputs instanced above. The book takes its place in Rancière's larger project: to identify and reconstitute the political, as it is manifested both in art and in the organisation, consumption and context of artworks. It is part of his ongoing series of arguments about the nature of visual images and their effectiveness within culture. And it provides both a parallel commentary and a set of challenges to contemporary theatre's turn towards spectator engagement. $^{2}$

\footnotetext{
${ }^{2}$ Rancière addresses the split between viewing and acting from a different perspective in 'Good Times, Or, Pleasure at the Barrière', in Rancière, trans. by David Fernbach, Staging the People: The Proletarian and His Double (London and New York: Verso, 2011), pp. 175-232. He explores a 'displacement' through the second part of the nineteenth century from forms of popular performance that involved their audiences also as inhabitors of artworks (hence, 'the workshop poet in his relationship with his brothers') to those that constructed a more disconnected kind of spectatorship (featuring 'the artiste in his or her responsibilities towards their popular audience') ( $p$. 213). The Emancipated Spectator addresses a different trajectory, from
} 
Rancière's focus in The Emancipated Spectator tends to be on art that can be looked at. Just looking, Rancière observes, can be dangerous, for 'To be a spectator is to be separated from both the capacity to know and the power to act'. ${ }^{3}$ Spectators cannot 'know' since the process of production is not represented. They are by definition separated from the power to act, since spectators watch. Rancière notes the argument (without quite doing anything as categorical as propose it himself) that there should be 'a theatre without spectators, where those in attendance ... become active participants as opposed to passive viewers'. ${ }^{4}$ The artwork, in this analysis, should rather transform spectators 'into active participants in a shared world ... [for] [e]mancipation begins when we challenge the opposition between viewing and acting' ${ }^{5}$

If this appears drastic, Rancière acknowledges a balance of considerations. As he wryly notes, 'Being a spectator ... is our normal situation'. ${ }^{6}$ And in any case, 'The spectator also acts ... She observes, compares, interprets. ... She composes her own poem with the elements of the poem before her'. 7 Spectatorship is not effort-free, not as passive as all that, and throughout the piece Rancière troubles 'the established relations between seeing, doing and speaking. ${ }^{8}$ The agenda is to identify new configurations of spectatorship that replace a relatively detached looking with more overt forms of engagement.

detachment to enhanced engagement, but from a similar view of the pertinency of relations between artistic production and consumption.

${ }^{3}$ Ibid., p. 2.

${ }^{4}$ lbid,. p. 4.

${ }^{5}$ Ibid., pp. 11, 13.

${ }^{6}$ lbid., p. 17.

${ }^{7}$ Ibid., p. 13.

${ }^{8}$ Ibid., p. 19 (original emphasis). 
Rancière often writes glancingly and allusively. It is productive to composite a case from the analysis developed across a number of different lectures and essays rather than derive it from any single output. His work circulates around certain key terms and understandings, albeit that the precise configuration of these shifts across various writings. Characteristically, terms are shaded with nuance, complication and sometimes counter-intuitive readings, and often entail a sort of negative definition. Hence 'emancipation' is not so much liberation as the possibility of disagreement. The 'emancipated spectator' is not a looker-on but someone who is involved. Which raises all sorts of questions for spectatorship, agency and participation.

In order to elaborate spectator engagement and address some of the problems it poses, I will explore Rancière's use of three key terms: 'Equality', 'Dissensus' and 'Sensus communis'. ${ }^{9}$ I argue below that these contribute to a nexus of ideas that run through his work more broadly and help to create the underpinning texture of The Emancipated Spectator. I then consider how they might apply to a variety of encounters between spectator-participants and artworks or events in Chicago, a city that offers a rich diversity of cultural engagements. For present purposes, I focus on a studio theatre production, a civic sculpture, a museum event and a basketball game.

\section{Equality}

\footnotetext{
${ }^{9}$ For a useful glossary of Rancièrean terms, including 'Equality' and 'Dissensus' (but not 'sensus communis'), see Gabriel Rockhill, 'Glossary of technical terms', in Jacques Rancière, The Politics of Aesthetics, ed. and trans. by Rockhill (London and New York: Continuum, 2004), pp. 80-93.
} 
Equality stands as an abiding principle across much of Rancière's work. It is understood as the capacity for individuals to take their own perspectives, and be free of what Rancière describes as 'the police' - an ordering function in society that establishes commonalities and conformities, thereby enforcing inequitable power structures. ${ }^{10}$ Equality is bound up with the political. As Rancière observes in Disagreement: 'Politics ... is that activity which turns on equality as its principle. ${ }^{11}$ To that end, as Steven Corcoran notes, politics is 'an activity in which all can partake'. ${ }^{12}$ Equality betokens the prospect of individual agency. Something similar might be said of performance, in the light of The Emancipated Spectator. One of the threads through Rancière's thinking concerns the ability of (or at least the desirability for) individuals to think and act for themselves.

Rancière presents a case for a radical understanding of equality in The Ignorant Schoolmaster: Five Lessons in Intellectual Emancipation, where he addresses the pedagogic principles of Joseph Jacotot. ${ }^{13}$ A Frenchman, Jacotot found himself teaching literature in the Flemish city Louvain in 1818.

\footnotetext{
${ }^{10}$ Zizek describes 'the police' as 'the structured social body where each part has its place' (Slavoj Zizek, 'The Lesson of Rancière', in Rancière, The Politics of Aesthetics, pp. 69-79 [p. 70]). See also Todd May, Contemporary Political Movements and the Thought of Jacques Rancière: Equality in Action (Edinburgh: Edinburgh University Press, 2010), pp. 9, 108; and, taking issue with May's 'anarchist project', Samuel A. Chambers, 'The Politics of the Police: From Neoliberalism to Anarchism and Back to Democracy', in Reading Rancière: Critical Dissensus, ed. by Paul Bowman and Richard Stamp (London and New York: Continuum, 2011), pp. 18-43 (p. 20).

${ }^{11}$ Jacques Rancière, Disagreement: Politics and Philosophy, trans. by Julie Rose (Minneapolis: University of Minnesota Press, 1998), p. ix.

${ }^{12}$ Steven Corcoran, 'Editor's Introduction', in Jacques Rancière, Dissensus: On Politics and Aesthetics, ed. and trans. by Corcoran (London and New York: Continuum, 2010), pp. 1-24 (p. 7).

13 Jacques Rancière, The Ignorant Schoolmaster: Five Lessons in Intellectual Emancipation, trans. by Kristin Ross (Stanford: Stanford University Press, 1991).
} 
He undertook an experiment whereby he asked students who spoke only Flemish to read a book in French, with a parallel translation; learn the translation by rote; then write about the book - in French. He found that they did so with aplomb. The discovery, as Rancière assesses it, was of the power of intelligent self-development. What, in that case, was a teacher? Perhaps even, what use a teacher? For Jacotot, the teacher who explains is in a structural relationship with someone who needs something explaining to them - therefore, someone definitively inferior in the teacher-pupil relationship. As Rancière engagingly suggests, 'It is the explicator who needs the incapable and not the other way around ... To explain something to someone is first of all to show him he cannot understand it by himself. ${ }^{14}$ Jacotot's premiss, by contrast, was to establish a mode of relation whereby both teacher and pupil would learn together - with learning enabled by a facilitator rather than an elucidator. Rancière suggests:

The method of equality was above all a method of the will. One could learn by oneself and without a master explicator when one wanted to, propelled by one's own desire or by the constraint of the situation. ... one can teach what one doesn't know if the student is emancipated, that is to say, if he is obliged to use his own intelligence. ${ }^{15}$

Rancière's enjoyment of this model is consistent with a sustained antiauthoritarianism in his work, and of course it chimes with developments in

\footnotetext{
${ }^{14}$ Rancière, The Ignorant Schoolmaster, p. 6.

${ }^{15}$ Ibid., pp. 12, 15. For an account of the principles of Jacotot's pedagogy, see Nick Hewlett, Badiou, Balibar, Rancière: Re-thinking Emancipation (London and New York: Continuum, 2007), p. 93.
} 
learning and teaching practices that favour independent enquiry. Mark

Robson observes in Jacotot's scheme 'the community of equals, a community based on the presumption of a shared intelligence, a shared capacity'. ${ }^{16}$ The model is inherently levelling. Everyone has the same prospect of access to knowledge and an equality of competence is assumed. The paradox of the ignorant schoolmaster is analogous to that of the spectator who is also an actor - equally engaged in activity, capable of independent action and thought. The Emancipated Spectator is built on foundations laid by Joseph Jacotot.

Equality applies communally, in that it entails equivalent prospects and opportunities across groups. This is, nonetheless, not a theory of mass action. Rancière's conception of the communal proposes a free space of individuation. That's to say, communities are not so much defined by their togetherness as by their facilitation of difference, the fact that they enable individual expression. There is a trace of Rancière's poststructuralist inheritance here. As Peter Hallward puts it, 'When crowds form in Rancière's work, it isn't (as with Sartre) in order to storm the Bastille or its contemporary equivalents; they come together to stage the process of their own disaggregation. ${ }^{17}$ Strikingly, the model of equality is in some respects a model for individual libertarianism within a communal (shared) context.

\footnotetext{
${ }^{16}$ Mark Robson, 'Jacques Rancière's Aesthetic Communities' in Jacques Rancière: Aesthetics, Politics, Philosophy, ed. by Robson, Paragraph, 28.1 (March 2005), 77-95 (p. 84).

${ }^{17}$ Peter Hallward, 'Staging Equality: Rancière's Theatrocracy and the Limits of Anarchic Equality', in Jacques Rancière: Politics, History, Aesthetics, ed. by Gabriel Rockhill and Philip Watts, (Durham \& London: Duke University Press, 2009), pp. 140-57 (p. 147).
} 
The axes of this thinking are threefold, and readily apply to an understanding of what it is to be one among spectators. Equality is desirable. It is predicated upon a sense of the capacity of each and every individual. The facilitation of difference characterises a productive relationship to one's community (with which one is able to disagree) - and is a feature of the operation of equality.

\section{Dissensus}

In thesis 8 of 'Ten Theses on Politics', Rancière suggests that 'The essence of politics is dissensus. Dissensus is not a confrontation between interests or opinions. It is the demonstration (manifestation) of a gap in the sensible itself. ${ }^{18}$ The sensible, in Rancière's usage, indicates that which is perceived and felt. The distribution of the sensible (partage du sensible), his celebrated coinage, evokes the manner in which things (artefacts, events, social transactions) are disposed for feeling and perception through cultural production and consumption. Rancière develops the idea that the sensible can entail a break in and of perception in Aesthetics and its Discontents:

Politics consists in reconfiguring the distribution of the sensible which defines the common of a community, to introduce into it new subjects

\footnotetext{
18 Jacques Rancière, Dissensus: On Politics and Aesthetics, ed. and trans. by Steven Corcoran (London and New York: Continuum, 2010), p. 37 . The article was first published in English in 2001, trans. by Rachel Bowlby and Davide Panagia, in Theory and Event, 5:3. See http://www.after1968.org/app/webroot/uploads/RanciereTHESESONPOLITIC S.pdf [accessed 11 March 2012].
} 
and objects, to render visible what had not been, and to make heard as speakers those who had been perceived as mere noisy animals ... creating dissensus. $^{19}$

As he goes on to suggest, dissensus means that 'every situation can be ... reconfigured in a different regime of perception and signification'. ${ }^{20}$

There is a Brechtian aspect to this, and one can draw a dotted line from Brecht's idea of verfremdung (whereby things that we thought we knew only too well are made strange, defamiliarised) to Rancière's argument that a redistribution of the sensible is politically efficacious. The latter case is couched in terms that do not depend, as Brecht's analysis does, upon the need for meaning as an overt outcome. Brecht is rearticulated to accord with contemporary modes of production. These are not necessarily rationalist in their operation. They may instead produce affect, sensation and experience new feeling, or what Rancière describes as 'a sensorium, a new partition of the perceptible,21 - rather than (Brechtian) new awareness and right-thinking. Rancière is careful to note that the fact of a redistribution of the sensible isn't in itself a guarantee of 'a new topography of the possible', a formation that might be understood to describe a sort of political and social efficacy. Rather, one seeks 'scenes of dissensus' in the face of the 'beast' of consumerism and commodification. $^{22}$ This is a project for artists and arts practitioners, you'd think, who might seek to facilitate such scenes. It is also a project for critics,

19 Jacques Rancière, Aesthetics and its Discontents, trans. by Steven Corcoran (Cambridge and Malden MA: Polity Press, 2009), p. 25. First published in French as Malaise dans l'esthétique (Editions Galilee, 2004). ${ }^{20}$ Ibid., p. 49.

${ }^{21}$ Rancière, Dissensus, p. 122.

22 Ibid., p. 49. 
who might identify scenes of dissensus in and through a disruption of commodification.

Despite its scrupulous basis in difference and dissent, there is something troubling or, at least, volatile about this model. Dissensus depends upon momentary configurations rather than ongoing transactions between groups of consolidated identity. It requires a break, a split or a fissure - it endlessly needs change. The model of equality developed is productive in that it implicitly renounces the sentimentalism of a homogenising, conformist view of communal identity. Nonetheless it is partial. Peter Hallward asks sceptically:

To what extent does Rancière's conception of equality remain a merely transgressive one? [...] Rancière's emphasis on division and interruption makes it difficult to account for qualities that are just as fundamental to any sustainable political sequence: organization, simplification, mobilization, decision, polarization, taking sides, and so forth. ${ }^{23}$

If dissensus always requires new configurations, it is difficult to conceive of it in terms of a systematic political project designed to secure measured and lasting benefits. This relates to the play between individual and communal experience discussed briefly above. Rancière is not really interested in dissensus as a programme of collective action or expression - rather, it appears to have more to do with a form of cultural transaction that is available to individuals in a moment of change or new awareness.

${ }^{23}$ Hallward, 'Staging Equality’, pp. 153, 155. 
According to Rancière, The Emancipated Spectator marks 'a change of approach' with regard to a critical project understanding the relation between the individual and society, and the prospect of politically efficacious emancipatory practices. ${ }^{24}$ There is no explicitly political project as such, no sense of converting, mobilising, rescuing or educating a group.

What there is are simply scenes of dissensus, capable of surfacing in any place and at any time. What 'dissensus' means is an organization of the sensible ... It means that every situation can be cracked open from the inside, reconfigured in a different regime of perception and signification. To reconfigure the landscape of what can be seen and what can be thought is to alter the field of the possible and the distribution of capacities and incapacities. This is what a process of political subjectivation consists in: in the action of uncounted capacities that crack open the unity of the given and the obviousness of the visible, in order to sketch a new topography of the possible. ${ }^{25}$

Dissensus occurs through difference and alteration. Its consistency lies in Rancière's insistence that it form part of a texture of aesthetic-political exchange. Spectators, then, engage to greater or lesser extent with and within 'scenes of dissensus'.

\section{Sensus Communis}

${ }^{24}$ Rancière, The Emancipated Spectator, p. 48.

${ }^{25}$ Ibid., pp. 48-49. 
Rancière's essay 'Aesthetic Separation, Aesthetic Community' in The Emancipated Spectator discusses, in part, a project by the artists' collective Campement Urbaine (Urban Encampment) which created a space of solitude in Sevran-Beaudottes, a down-at-heel suburb of Paris. The essay leads off with Mallarmé's proposition, 'Apart, we are together'. ${ }^{26}$ Rancière is attracted to this conceit, and his essay in effect suggests that together we are also apart: 'To the extent that it is a dissensual community, an aesthetic community is a community structured by disconnection'. ${ }^{27}$

Such disconnection was realised emblematically by Campement Urbain in Je et Nous (2003-6), the subject of Rancière's analysis. Among its other outcomes, the project manifested a space that could only be occupied by one person at a time. Oliver notes that the community evoked (indeed facilitated) by this work "will necessarily be a "dissensual" community, whose members reinterpret the works they encounter in the light of their own experiences and their knowledge of other works'. ${ }^{28}$ You could say that this is the case when any individual takes herself to an event, installation or performance, and that Je et Nous simply throws the interpretative role of the spectator into starker relief. The space for solo occupation is emblematic, for if each spectator 'composes her own poem', as Rancière puts it, ${ }^{29}$ we must acknowledge the endless variation across individual engagements. Davis nevertheless wonders how Rancière's 'insistence ... on the dissensual character of the community'

\footnotetext{
${ }^{26}$ Ibid., p. 51.

${ }^{27}$ Ibid., p. 59.

${ }^{28}$ Oliver Davis, Jacques Rancière (Cambridge and Malden MA: Polity Press, 2010), p. 155.

${ }^{29}$ Rancière, The Emancipated Spectator, p. 13.
} 
can be squared with his otherwise 'broadly Kantian vision', to do with 'the development of a consensual community'. ${ }^{30}$ Davis suggests that Rancière has rather too hastily privileged dissensus over consensus.

It is the case that 'consensus' is rather a dirty word in Rancière's work, smacking as it does of bland agreement and the subtle (or not so subtle) operations of that which constitutes the 'police'. 'Consensus' implies a set of assumed norms that are nonetheless held in place by vested interests, and that serve to sustain power structures that do not foster equality. In 'Ten Theses on Politics' Rancière argues that

The essence of consensus ... does not consist in peaceful discussion and reasonable agreement, as opposed to conflict or violence. Its essence lies in the annulment of dissensus as separation of the sensible from itself ... Consensus is ... simply a return to the normal state of things - the non-existence of politics. ${ }^{31}$

This non-existence, as we have seen, means the absence of difference, and the sway of convention and conformity. ${ }^{32}$

There is a distinction to be drawn, however, between consensus and community, and the latter term runs as a shadow through Rancière's thinking.

${ }^{30}$ Davis, Jacques Rancière, p. 157.

${ }^{31}$ Rancière, Dissensus, pp. 42-43.

${ }^{32}$ Rockhill traces a development in Rancière's thinking whereby the distinction between consensus and dissensus becomes less strictly marked. It nonetheless remains decisive. See Gabriel Rockhill, 'The Politics of Aesthetics: Political History and the Hermeneutics of Art', in Jacques Rancière: Politics, History, Aesthetics, ed. by Gabriel Rockhill and Philip Watts (Durham \& London: Duke University Press, 2009), pp. 195-215 (pp. 200-15). 
We've already seen that a conception of 'the common' - the gathered interests of a group - is important here. This needs teasing out a little. In his 'Afterword' to a collection of essays by others on his work, Rancière observes that 'A common sense does not mean a consensus but, on the contrary, a polemical place'. ${ }^{33}$ In 'Aesthetic Separation, Aesthetic Community' he writes:

What is common is 'sensation'. Human beings are tied together by a certain sensory fabric, a certain distribution of the sensible, which defines their way of being together; and politics is about the transformation of the sensory fabric of 'being together'. ... An aesthetic community is not a community of aesthetes. It is a community of sense, or a sensus communis. A sensus communis involves three forms of community. ${ }^{34}$

The first form, in Rancière's scheme, is 'a certain combination of sense data'. ${ }^{35}$ The second Rancière terms a 'dissensual figure', entailing conflict or contradiction - he suggests that this is between artistic representation and power structures, form and context. The third level entails 'a community between human beings', which sounds rather vapid and is glossed, more particularly, as the sense of community that arises when the first level (sense data) itself relates to the second ('the intertwining of contradictory relations'). ${ }^{36}$ I take this to mean the realisation, in mind, body or both, of divergent

33 Jacques Rancière, 'Afterword: The Method of Equality: An Answer to Some Questions', in Jacques Rancière, ed. by Rockhill and Watts, pp. 273-88 (p. 277).

${ }^{34}$ Rancière, Aesthetics and its Discontents, pp. 56, 57.

${ }^{35}$ Ibid., p. 57.

${ }^{36}$ Ibid., p. 57. 
possibilities (Rancière's new topographies of the possible) - perhaps, better, the experience of that realisation.

Sensus communis, then, is an important and intriguing coinage. It is not at all the same as 'consensus' in the Rancièrean lexicon. It is not blind or blank agreement for the sake of it. Instead it is the experience of being located meaningfully within a community. It evokes the longstanding leftist view of the centrality of community to effective social interaction. It does so by gesturing towards the tropes of an individualist (indeed a consumerist) era, such as subjective perception, felt experience and personal engagement. Herein lies the congruence with the notion of dissensus, for it is as individuals that we experience community, and we do so insofar as the aesthetic realm facilitates our dissensual relationship with cultural production.

The relationship between community (or 'the common') and dissensus (or difference) needs careful calibration. As Jean-Luc Nancy says, 'One could extrapolate from Rancière that art is a means (and perhaps the most common one, considering all the forms of knowledge and power) of understanding our communal existence and the very modes of being-in-common (what brings us together and separates us) ${ }^{37}$ That seems right, and yet this isn't quite the same as saying that art produces communities as homogenous groupings, nor that it is even necessarily about the desirability of communities. There is a countervailing scepticism in Rancière's work concerning what might be thought the too-easy or sentimental view of the beneficent aspects of community (or indeed, we might add, a gathered audience). Rancière would

\footnotetext{
${ }^{37}$ Nancy, Jean-Luc Nancy, 'Jacques Rancière and Metaphysics', trans. by John Hulsey, in Jacques Rancière, ed. by Rockhill and Watts, pp. $82-92$ ( $\mathrm{p}$. 92).
} 
much rather emphasise the prospect of difference and separation.

Nonetheless, he does so according to the implicit premiss that 'being-incommon', to use Nancy's phrase, is preferable to the segmentations and subjectivations of the police order.

In The Emancipated Spectator Rancière discusses the community that pertains to theatre by way of the engagement of spectators. The means by which performances transcend the separation of stage and auditorium entail the figuring of individuals in 'their place of communion. For the refusal of mediation ... is the affirmation of a communitarian essence of theatre as such. ${ }^{38}$ Mediation is nowhere more emphatically refused than in the moment when the spectator is folded into the event. We are interested, then, in situations where spectators are not passive. These situations will say something about modes of spectatorship and their relation to cultural production, politics and pleasure.

\section{Spectator engagements in Chicago}

In Chicago in 2010 I experienced a number of scenarios where spectating was itself rendered visible; where the ingraining of the spectator into the event (or artefact) was an important feature; and where in various ways I saw myself in the act of spectating. I propose to explore how Rancière's thinking might

${ }^{38}$ Rancière, The Emancipated Spectator, pp. 15-16. 
apply to - or be tested by - these instances, and address their connections with more widespread developments in spectatorship. Taken together they help to illustrate larger questions, possibilities and tendencies in the relationship between a 'spectator' and an 'event'.

\section{A studio theatre production}

The Twins Would Like to Say was presented by Dog \& Pony Theatre Company at Steppenwolf's Merle Reskin Garage Theatre, a studio space underneath a car park next to Chicago's celebrated Steppenwolf Theatre. ${ }^{39}$ The production was programmed as part of Garage Rep, Steppenwolf's Visiting Company Initiative designed to promote 'new, provocative work emerging from Chicago's diverse and vibrant theatre scene'. ${ }^{40}$ Established in 2002, Dog \& Pony Theatre Company started out by staging contemporary plays - Michael Frayn's Clouds (Chicago Cultural Center, 2004), Osama the Hero by Dennis Kelly (Athaneum's Studio \#3, 2005) Sheila Callaghan's Crumble (Lay Me Down, Justin Timberlake) (Athenaeum's Studio \#2, 2005) and was named 'Best Theater Troupe' by Chicago Magazine in 2007. The company turned to devising pieces, working with extant materials and a looser engagement with space and setting. As Told By the Vivian Girls (Theater on the Lake, Fullerton \& Lake Michigan, 2008), adapted from the circumstances, drawings and writings of the reclusive artist Henry Darger, was presented as a promenade piece in a two-storey former sanitarium. In a manner reminiscent

\footnotetext{
${ }^{39}$ The production ran from 18 February - 25 April 2010. I saw it on 1 April 2010.

${ }^{40}$ Press release for The Twins Would Like to Say. Dog \& Pony Theatre Company's website is at http://www.dogandponychicago.org/index.php [accessed 22 November 2011].
} 
of Punchdrunk's Masque of the Red Death (2007), the audience wore masks and wove their own journeys through simultaneous scenes of performance. The Twins Would Like to Say involved the audience in movement largely through and around the Steppenwolf Garage studio. The production was not site-specific, in that its action did not depend on the specificities of this particular studio, nor its location. It took the mode of promenade as a means to provide perspectives on the drama and, perhaps, to freshen up a viewing experience that could just as easily (given the story and its mode of telling) have been end-on.

Written and directed by Seth Bockley and Devon de Mayo after an initial devising process, The Twins Would Like to Say dramatises the unusual story of the identical twins June and Jennifer Gibbons, Caribbean immigrants to Wales. In the 1970s the twins lived out a pact to speak only to each other, which in part saw them committed to Broadmoor, a secure psychiatric hospital. ${ }^{41}$ Dog \& Pony's production began with a prologue in the theatre's foyer, involving puppets of parrots and a Master of Ceremonies character called 'Mr Nobody'. The audience was led by this figure into the studio, in which we traversed through a corridor made of black drapes, running through the middle of the space, therefore dividing it into sections and creating a destabilising effect - we didn't know quite where we were going, nor what was at the other end, nor what the space's proper proportions were. A preliminary

\footnotetext{
${ }^{41}$ The play draws on The Silent Twins, Marjorie Wallace's biographical account (London: Vintage, 1998 [1986]). Wallace's book followed her screenplay for a docudrama, The Silent Twins (BBC2 1986). It informed an opera, also entitled The Silent Twins, by April de Angelis and Errollyn Wallen (Almeida Theatre, London, 2007) and Shared Experience's production Speechless, presented at the Edinburgh Festival in August 2010. The story of June and Jennifer Gibbons has inspired other artworks, including the Manic Street Preachers' song Tsunami (1999).
} 
scene introduced us to the twins, played by and Paige Collins and Ashleigh LaThrop. We were then led into the larger spaces of the studio, which was arranged by designer Grant Sabin as a set of stations of performance, each broadly figuring a specific setting. There was a lounge, for instance, a bedroom, and a doctor's office (Fig. 1). Some of the scenes took place in more transient or de-located sorts of space - as with the exchanges between the twins and two blonde girls from their town, or those with a boy who strikes up a sort of friendship with them.

\section{[insert Figure 1]}

The audience gravitated towards these various settings, standing and disporting themselves around the foci of action. There was a certain casualness to this, especially as the show went on and we became more familiar with the pace, format and rules of engagement. We sat on rostra on either side of the bedroom set, for instance, to watch a scene played end-on by Collins and LaThrop. In other instances, scenes took place simultaneously, so we choose which to watch, or drifted between different physical settings in order to catch something of everything. The show, then, figured certain sorts of fluidity, decentring, multi-perspectival possibilities and seriality - its form gestured towards fracture as opposed to strict linearity, albeit that the play (for this was, decidedly, a play) told its story chronologically and the production was more restrained in its dismantling of space than might have been the case. 
The style of the piece was also mixed. The show was part-narrated. It featured broadly naturalistic scenes. It included shadow and rod puppets and a cartoon-like pastiche (the story of a boy addicted to Pepsi). The twins unfolded a picture book to tell of the burning down of a school. There were some choreographed movement figures expressing, for instance, the routine of the girls' mother and father on the sofa watching TV, or the doctor and Mr Nobody in the doctor's office. The twins danced in a sequence dealing with a fantasy-story involving a trip to the disco.

Toward the end of the production a curtain was drawn across the studio, dividing the playing area in two. The simultaneous scenes that closed the piece entailed both a denial of spectating (for the first time, given we had previously been free to choose what to watch) and a privileged viewing access (in that one half of the audience saw something denied to the other half).

The production was not particularly groundbreaking, but usefully exemplifies some tendencies in this sort of promenade performance. Actions were presented in different parts of space. The spectators had relative freedom of movement. The staging entailed fairly frequent changes of position, so that there was a continual negotiation of one's viewing space alongside others. The audience was treated as a community of individuals facilitated in making small decisions as to what to watch and how, or from where, to watch it. A not inconsiderable feature of this was that one became very aware of other spectators. They were in your sight line, sometimes in your way, sometimes in a space that you'd like to be standing in, or else you politely adjusted your position in order to facilitate someone else's viewing. 
We didn't just watch the drama. We observed and accommodated acts of observation.

The configurations enabled some low-level effects of dissensus - the feeling of seeing things differently, of not having drama presented for the gaze, but rather textured into a space that itself became a site of freer flow and negotiation. This returns me to the point that dissensus can achieve its effects as if innocent of meaning or cognition. The production created a texture of affect a little different from that of theatre pieces where the spectator sits in a single place and watches. Were we emancipated? Perhaps it suffices to say that we were free to make modest choices relating to positions of viewing. This in itself is a figure for a cultural process that dislodges us from fixed perspectives and moves us towards divergent places of engagement. In its contained way, The Twins Would Like to Say performed a nod towards a spectator who is in action rather than inactive.

\section{A civic sculpture}

Cloud Gate, nicknamed 'the Bean', is a public sculpture by Anish Kapoor. Located in the AT\&T Plaza in Chicago's Millennium Park, it is made of 168 stainless steel plates, highly polished to provide a seamless reflective surface, that displays both the surrounding cityscape and the observer in slightly distorted perspectives (Fig. 2). It was unveiled in a partially completed form in 
2004, as part of the opening of Millennium Park, and formally on 28 August $2005^{42}$

\section{[insert Figure 2]}

Kapoor explored the possibilities of a series of reflective orbs and roundels in the late 1990s, and Cloud Gate connects with the pieces in his wider 'void language' and 'mirror language' series. ${ }^{43}$ His sculpture Turning the World Inside Out (1995) - a steel ball, dimpled on top - displayed a similar fascination with the exuberant gathering of reflection (in this case the ground, ceiling and walls of the gallery, all co-present to the gaze). In Iris (1998) a convex stainless steel mirror, placed either on floor or wall, plays back the surrounding space in a way that both condenses it (within the circle) and releases it (through the distortions and abstractions of the convex form). Iris makes an eye of itself whilst staging the act of viewing. This play of perspectives and incorporation of the viewer into the scene of the sculpture occurs in another civic piece, Sky Mirror (2006), located in the Rockefeller Centre in New York. This is in effect a huge two-sided mirror formed of a stainless steel disc 10.5 meters in diameter, tilted at an angle of sixty degrees. The convex side of the sculpture points downwards, meaning that viewers can

\footnotetext{
${ }^{42}$ See Cheryl Kent, Millennium Park Chicago (Evanston, Illinois: Northwestern University Press, 2011), pp. 31-49, for an account of Cloud Gate's conception, construction and completion, in which the contributions of structural engineer Christopher Hornzee-Jones and the project's fabricator, Ethan Silva, are writ large.

${ }^{43}$ For images, see Anish Kapoor, ed. by David Anfam (London and New York: Phaidon, 2009), pp. 217-55 and 337-39; and Rainer Crone and Alexandra Von Stosch, Anish Kapoor (Munich, London and New York: Prestel, 2008), pp. 41-42, 90, 99.
} 
see themselves reflected. The concave side points upwards, embracing skyscrapers and sky, to create an image that looks peculiarly out of place against the sombre backdrop of the Rockefeller Centre's neo-classical façade.

Cloud Gate takes the two separate sides of Sky Mirror and puts them together in a different shape entirely. It is a machine for spectating. As an art object, its function is to be viewed within its situation. Cool, calm and contextual, it squats in the Plaza as a sophisticated sort of eye candy. The sculpture's organic shape (evoking a coffee bean or a kidney), curved lines and pristine surfaces are sensuous and seductive in themselves. More pertinently, however, Cloud Gate restages the city that surrounds it. Chicago is figured in 360 degrees, with the sculpture providing a panoptical survey of plaza, park, skyscrapers and sky. The city is the most densely populated in the world in terms of high-rises. Cloud Gate - its name indicating the aerial scope of this crouching piece - pictures the city in both horizontal and vertical axes, embracing its buildings, citizens and visitors, and opening out to the heavens.

Whilst the Bean enables a vernacular replaying of Chicago to itself, its key enticement is the way in which it entails a form of motional spectating. 'I believe in the making of art, the viewer is all important,' says Kapoor. ${ }^{44}$ You walk around Cloud Gate to view its (re)perspectives on the city. And you view yourself in the act of viewing. Visitors experiment with stepping closer to and further from the sculpture, testing its hall-of-mirrors effect on their bodies and groupings. People photograph themselves in touristic delight at the sculpture's warping remediations. As Crone and Von Stosch suggest, it produces 'a kind

${ }^{44}$ Quoted in Kent, Millennium Park Chicago, p. 32. 
of estrangement for the spectator who must also decode a distorted view of his own shape among the others. ${ }^{45}$ The work is tactile. Kent observes that, 'Invariably, people also touch it as if to verify that the object really is present. ... There were fingerprints everywhere on the sculpture that evening, going up as high as a person could reach. ${ }^{46}$ And you walk into and through the Bean, for Cloud Gate is a form of gateway. Rather than open onto any particular new territory, it provides a pure passage through a curved arch from one side to the other, an emphatically processual walking through. Not that you simply traverse. At its apex the arch is around 12 feet high, and it gives onto an omphalos whose centre is 27 feet high, its concave ceiling serially distorting the reflections of those beneath (Fig. 3). You stop in the middle, to admire the sudden vortexical dynamic of the reflection presented above you (Fig. 4). This peculiar void, reminiscent of the black holes in otherwise diverse pieces by Kapoor such as Descent into Limbo (1992), Marsyas (2002) and Marsupial (2006), sucks its spectators into a sudden rendition as tiny figures seen at a seemingly impossible distance.

\section{[insert Figures 3 and 4]}

Cloud Gate's dissensual character lies in its reimaging of Chicago, the refiguring of its spectators, and the incessant movement of individuals taking up subject-viewing positions that simultaneously place them as objects within - and interactants with - the sculpture's larger mise en scène. It is egalitarian, a civic artwork that is available to all, but in the terms in which Rancière

${ }^{45}$ Crone and Von Stosch, Anish Kapoor, p. 43.

${ }^{46}$ Kent, Millennium Park Chicago, pp. 31, 35. 
describes the substance of equality. It facilitates dynamic individuation as the watchers (who are also in motion, in action) determine their own journey, pace and relation to the object. As David Anfam suggests, 'The fact that Kapoor's sculptures make us participants (by enticing us to peer in, walk around, guess their full extent and so forth), rather than just thinking observers, renders their hypnotism profoundly embodied. ${ }^{47}$ Does this also produce a sensus communis? Tourists and passers-by gather at Cloud Gate as participatory witnesses, and as individuals among a group of many, implicated in the dynamic and self-regulating act of spectating. In that sense Cloud Gate is an emblem for a pleasure-economy that commodifies presence, looking and selfrecognition, and does so en masse.

\section{A museum event}

As part of a trend in a number of museums and galleries, the Museum of Contemporary Art (MCA) in Chicago stages a monthly free-form rendezvous called 'First Friday'. As the museum's website explains:

Happy hour takes on a new meaning with First Fridays at the MCA. Relax after a long workweek with a cash bar featuring specialty drinks and free Wolfgang Puck appetizers. Enjoy live music from local DJs, the world's only iMac G5 digital dating bar, creation stations, and more. ${ }^{48}$

\footnotetext{
${ }^{47}$ David Anfam, 'To Fathom the Abyss,' in Anish Kapoor, ed. by Anfam, pp. 88-113 (p. 105).

${ }^{48}$ https://boxoffice.mcachicago.org/public/default.asp [accessed 22 November 2011]. I visited First Friday on 2 April 2010.
} 
First Friday extends the commercial activities of the organisation. According to MCA's sponsorship prospectus, the event has 24,000 opt-in email subscribers, a potent database:

\section{Attendance and Demographic}

The event attracts city influencers between the ages of 25-45. The crowd is ethnically diverse urbanites working in and around downtown Chicago, whose household income ranges from $\$ 75,000-250,000$ annually. On average, we welcome between 1,400-2,200 attendees to each event. $^{49}$

Such events refunction the spaces of the museum or gallery and put the viewer at the centre. They are perambulatory and participatory. When I visited the MCA's First Friday, the first thing I did was get a drink from the bar at one end of a gallery space, then some food from a large buffet branded with the name of an Austrian-American celebrity chef. A number of other people were milling around, eating, drinking and chatting. In a separate gallery was a table of petits fours, which one could consume standing on the terrace outside, looking out over nearby basketball courts towards Lake Michigan. The food facilitated a sense of purposive drift, as individuals, couples and groups percolated through the spaces, stopping to graze on the dips and chips. There wasn't necessarily anywhere to go, but the event created a texture of flow and impermanent settling as people moved around the building for the sake of taking a promenade or paused in order to rest, eat, watch or chat. It was

\footnotetext{
${ }^{49}$ http://mcachicago.org/assets/downloads/ff_sponsor.pdf [accessed 22 November 2011].
} 
possible to be a little more directional. I watched a group of people sitting around a set of tables making paper flowers (a 'creation station', Fig. 5); browsed around one of the exhibitions; then went upstairs, where a suite of iMacs featured an interactive task that indicated the types of people I might be attracted or attractive to. It was perhaps happenstance that the computers featured this particular software, although there is something emblematic about the focus on the inspection of others, and their inspection of you, in an event that is so readily to do with viewing, consuming and being available as a participant. The party aspect of First Friday underscored one of its signal features. The museum was curating us, making an exhibition out of its spectators, who were inherently both observers and observed. The gallery environment enhanced the watchability of those present. The trope of looking, intrinsic to the museum's function, was revitalised in a set of transactions that offered different sorts of sensory stimuli. The museum's usual mise en scène was refunctioned as a mise en événement, an arrangement of spaces and engagements that created a participatory encounter, the purpose of which was entirely to be experiential.

\section{[insert Figure 5]}

It was here among strangers, perhaps more so than among different strangers at the Steppenwolf Garage or the AT\&T Plaza, that I felt the sensus communis of which Rancière writes. The 'sensory fabric' of the museum was refigured by certain small and arguably dissensual rearrangements of its spatial organisation. I was folded into the galleries as a participant rather than 
an observer, yet I was free to be a gawper, guzzler or chatterer entirely as I chose, in each case refuting the museum's main identity as a repository of cultural artefacts and a place of contemplation. Such possibilities are fairly trivial in the grander scheme of cultural process, but they nonetheless figure such a process where it offers a form of demotic agency, multiple options for pace and focus, and consumption according to personal preferences. It might be argued that this wasn't exactly the communis Rancière had in mind when he wrote of Campement Urbain and the opportunity to contemplate difference - not least given the MCA's account of the wealthy demographic of its visitors. I shall return to this reservation after my last instance of spectator engagement in Chicago.

\section{A basketball match}

On 3 April 2010 the Chicago Bulls played the Charlotte Bobcats at the United Centre in Chicago's West End. Figure 6 shows the basketball arena. The central dais above the playing area gives spectators the chance to see the action in close-up, follow timings and statistics relating to the game, and view other messages, adverts and fillers. Electronic data bands around the arena convey messages either in still or moving form. The club lays on additional entertainment by way of the Luvvabulls (female cheerleaders), the Matadors (male dancers) and the IncrediBulls (comedy artists), who perform at diverse opportunities, including external events by arrangement. Mascot Benny the Bull, likewise, 'is available for personal appearances [and .... frequently attends birthday parties, community parades, festivals, walk-a-thons, school 
classroom appearances, college, high school and grade school sporting events, golf outings and more!' ${ }^{50}$

\section{[insert Figure 6]}

If this extends the reach of the club into its communities, spectator engagement during the course of the game takes a number of forms. In Figure 7 , the spectators at one end of the court, waving red and white balloons, are barracking a member of the Charlotte Bobcats who is taking a free shot. Signs are displayed that say 'BOO'. This might seem unsporting, but such involvement is packaged here as part of the fun of the event.

\section{[insert figures 7 and 8]}

Figure 8 shows The Dunkin' Donuts race. Three animated characters race around a small track. The spectators have a number on their ticket $-1,2$ or 3. The spectators with the number of the winner (in this instance \#1) can claim a free donut from the foodstalls in the foyer areas behind the seating blocks. A third are winners! There is more noise generated by this three-lap race than during the game itself.

There is a continuum between the engagement of the crowd during and outside gametime. Figure 9 shows an animated bull who drums and dances, and leads the crowd in a chant of 'Let's Go Bulls!' As Figure 10 indicates,

\footnotetext{
${ }^{50}$ The Bulls' website is at http://www.nba.com/bulls/. Game entertainment is detailed at http://www.nba.com/bulls/tickets/game time.html [accessed 22 November 2011].
} 
instructions to the spectator are relayed on the advertising strips around the arena and on the screens, with reactive graphics indicating how much noise is made and thereby encouraging the crowd to redouble its efforts.

\section{[insert Figures 9, 10, 11 and 12]}

During the breaks there are various sequences on the screens that feature the spectators at the event, who become briefly the focus of attention. Figure 11 shows a close-up of a spectator eating. Some of this material is clearly pre-recorded, given that the footage is sometimes sped up to make for some comic chomping. In another sequence, a cut-out head of hair appears on the screen. This frames the head of a spectator caught in a live close-up. Some of the spectators are watching the screen, others not, and the latter are nudged or called as the hairpiece settles on them. There are looks of recognition and recognisable utterances ('It's me!'), waves to the camera (Figure 12) and warm ripples of laughter from around the auditorium. In a sequence entitled 'Dance Fever', a live camera settles on individuals as 'Shake Your Boogie' plays. Individuals dance (or not) when on camera. Every now and then a recording of one or other of the Bulls players, dancing, is superimposed, further imbricating the spectators with the objects of their fandom.

[insert Figure 13] 
The audience gets its reward. Hot dogs attached to parachutes are shot from a cannon, to cheers from the crowd (Figure 13). The cannon operator waves at a section of the crowd. They respond, wave, stand. He shoots. People whoop. The screen shows the crowd. There is much self-presentation for the camera.

\section{The implicated spectator: consumer of the watchable}

Rancière suggests that 'The modern aesthetic break is often described as the transition from the regime of representation to a regime of presence or presentation'. ${ }^{51}$ We might add that the latter regime entails a further development, towards the presence and presentation of the spectator herself - the implication of the spectator in the event, where we do not just witness new modes of presence, but experience them as a key feature of our engagement. In the instances above, such encounters are structured dramaturgically (or quasi-dramaturgically) to theatricalise experience in the face of the event. The body's implication helps to valorise the event's (or object's) presence, disposition and - ultimately - its pleasurable watchability. Indeed, we become consumers of the watchable, where we are part of that which is consumed by others.

In an uncharacteristically direct statement, Rancière observes that 'Emancipation begins when we challenge the opposition between viewing and

\footnotetext{
${ }^{51}$ Rancière, The Emancipated Spectator, p. 121.
} 
acting' ${ }^{52}$ Yet the mere fact of such a challenge is not necessarily a guarantee of the dissensual expression of life within a culture that is celebrated in much of his work. What is the action undertaken by the non-passive spectator in the examples above? It is a sort of parallel engagement, a desired involvement of self (presence, body, action) in the fabric of the event, where the main mode remains one of watching - relatively risk-free. Here, however, one watches both the event (the play, civic sculpture, museum gathering, basketball game) and sees oneself in person, mirrored or on a screen, or in the echoing bodies of other spectator-participants. This may well produce the sensus communis of which Rancière speaks, but it is questionable whether it also routinely produces dissensus beyond a superficial refiguring of customary spaces and relations. The turn is rather towards the curated production of watchers as a guarantee of their engagement - facilitating a heightened sense of involvement in the now-moment, which is part of the commodification of time, presence and experience in late-capitalist culture. There is a would-be innocent pleasure in self-recognition, the striking moment where one says 'that's me!' and both experiences and observes oneself in the moment of participation, as simultaneously sensory subject (enjoying sensus) and meaningful object of a gaze that is both personal and shared with others (experiencing communis).

The appearance is of a redistribution of the sensible aspects of events and presentations. It suggests that we have moved from a society of the spectacle (objects out there to be seen) to a society of implicated spectaction (to adapt Boal's term 'spectactor'), where the spectator completes the event

\footnotetext{
${ }^{52}$ Rancière, The Emancipated Spectator, p. 13.
} 
through her active presence. And yet this is a neutral (or perhaps issue-lite) spectation. It folds the participant modally into its procedures, promising that we are part of the thing rather than merely witnesses to it.

Rancière's problematizing of the relationship between viewing and acting, is timely. It is the outcome of a grainy celebration, running through much of his writing, of work ethic, dignified artisanry, free agency and critical difference. Yet we cannot say that non-passivity liberates us, nor even that it will be dissensual. For whilst the spectator is implicated, the work itself - at least, in the instances above - remains peculiarly unenterable. You don't change the event, here; you merely complete it. Nor do you change yourself. Rather, you consume culture and enjoy the visual affirmation of yourself as participating consumer. In this matrix of engaged experience, the offer is of a safe, secure arrangement for redistributed spectating. The spectator is implicated, even incorporated, rather than emancipated.

I am reminded of Peter Hallward's suggestion, quoted above, that in Rancière's account crowds 'come together to stage the process of their own disaggregation'. They do, theoretically. But these particular crowds in Chicago acted as semi-free agents, expressing individual response and engagement, within a process of agglomeration. We are equally able to respond independently, but within the overarching arrangement of our place as consumers. Hewlett suggests that 'At times it is not clear if Rancière is in fact developing a praxis-informed, progress-oriented, emancipatory theory or if he is thinking more in aesthetic terms of the Utopian and an impractical ideal, which might ultimately inspire the practical but is itself quite removed from 
it'. ${ }^{53}$ This neatly articulates the dilemma of The Emancipated Spectator. We are free to view differently, indeed to act, but to what end?

Then again, perhaps in the face of these objects and events we are released into a sensus communis that is the antidote to consumerism even whilst it depends upon consumption. Rancière himself suggested as much. As he observes in relation to the trend towards reality art: 'In one respect, at issue is to restore a certain sense of community to counter the bonddissolving effects of consumerism'. ${ }^{54}$ That in itself is a form of dissensus not to be taken lightly.

${ }^{53}$ Hewlett, Badiou, Balibar, Rancière, p. 107.

${ }^{54}$ Rancière, Dissensus, p. 146. 